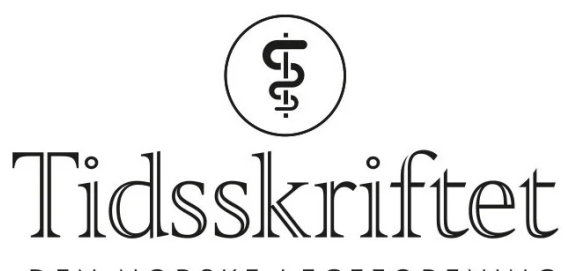

DEN NORSKE LEGEFORENING

\title{
Rettelse: Tidlig aktivitet hos respiratorpasienter - en metaanalyse
}

RETTELSE

HANNA EIKÅS KLEM

TUVA SOFIE TVEITEN

SIGRID BEITLAND

STINE MALERØD

DORIS TOVE KRISTOFFERSEN

TERESE DALSNES

MARIA BEATE NUPEN-STIENG

LILLEBETH LARUN

Tidsskr Nor Legeforen 2021; 141: 748-57.

I Tidsskriftet nr. 8/2021, s. 753 skal Figur 4 se slik ut: 


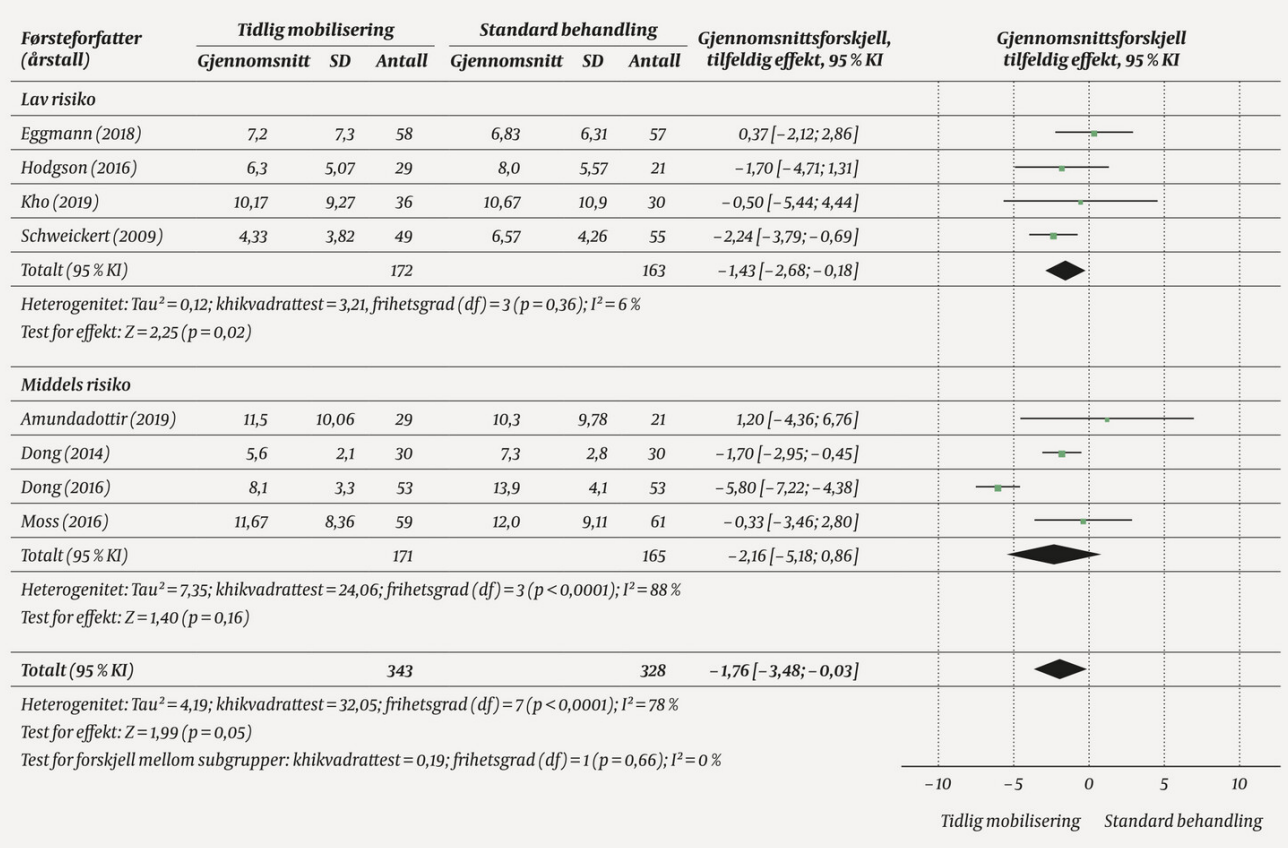

Figur 4 Balansediagram for utfallsmålet varighet av respiratorbehandling angitt $\mathrm{i}$ antall døgn. Sammenligning mellom tidlig mobilisering og standard behandling. Studier med middels risiko for systematisk skjevhet er inkludert (subgrupper).

Vi beklager feilen, den er rettet på nett.

Publisert: 21. juni 2021. Tidsskr Nor Legeforen. DOI: 10.4045/tidsskr.21.0485

(C) Tidsskrift for Den norske legeforening 2023. Lastet ned fra tidsskriftet.no 26. april 2023. 